\title{
Structural dividends and economic growth in China $^{* 1}$
}

\author{
Wang Zhenhua ${ }^{2}$, Sun Xuetao ${ }^{3}$, Zhang Guangsheng ${ }^{4}$
}

\begin{abstract}
This study aims at analyzing the impact of industrial structure upgrading on the economic growth of China. Based on panel data of 283 cities of China from 2001 to 2014, this paper uses the spatial panel SARAR to analyze the influence of industrial structure upgrading on the economic growth of China's prefecture-level cities. The results show that China's urban economic growth has significant spatial correlation: industrial structure upgrading is the prime reason for the economic growth and the differences in the urban economy in China, and the impact of structural dividend on economic growth is positive. However, with the further upgrading of the industrial structure, the structural dividend will become negative, i.e. there is a significant inverted " $U$ " relationship between the industrial structure and economic growth. The study provides new empirical evidence for the new classical economic growth theory and a new research experience for a follow-up study.
\end{abstract}

Key words: industrial structure upgrading, structural dividends, SARAR model, China

JEL classification: $C 25,011,013$

\footnotetext{
* Received: 22-01-2018; accepted: 12-06-2018

1 Acknowledgment: This work was supported by National Natural Science Foundation of China (No. 71503173), Social Science Foundation of Liaoning Province (No. L17AJY009) and Shenyang Science and Technology Plan Project (1801612).

2 Assistant Professor, College of Economics and Management, Shenyang Agricultural University, Shenyang 110866, China. Scientific affiliation: development economics. Phone: +862488487153. E-mail: wangzhenhuasyau@163.com.

3 Ph.D., College of Economics and Management, Shenyang Agricultural University, Shenyang 110866, China. Scientific affiliation: development economics. Phone: +86 2488487248. E-mail:qingbingsun@126.com.

4 Professor, College of Business, Liaoning University, Shenyang 110136, China. Scientific affiliation: development economics. Phone: +8613674283521.E-mail: huagewzhwzh@163. com (Corresponding author).
} 


\section{Introduction}

China is the second largest economy in the world. In 2017, China's GDP reached 82.71 trillion yuan, which is 224.82 times which in 1978. Some studies have found that industrial structure is an important variable affecting China's economic growth (see e.g., Yu, 2015). The effect of upgrading industrial structure on economic growth is called "structural dividend" (see e.g., Liu and Zhang, 2008). During the process of industrial structures upgrading, production factors from less efficient production departments are shifted to more efficient ones, thereby increasing total factor productivity of the economic entity and in turn, promoting economic growth, which is the existence of a structural dividend. (see e.g., Huang, 2014; Research Grop on China's Economic Growth, 2014). In recent years, China's economic growth has declined, and scholars have also attributed it to "structural slowdown". (see e.g., Research Grop on China's Economic Growth, 2014). The empirical research results show that structural dividend is one of the driving forces for rapid economic growth in the early stage of development in China. However, as the economy grows, this structural dividend continues to weaken. There are still some controversies in the research methods and conclusions of the existing literature (see e.g., Krugman, 1994; Liu and Zhang, 2008). Some studies have pointed out that the conversion share method will underestimate the structural dividend, and the structural change of capital may even have negative interest (see e.g., Yu, 2015).

The key research questions proposed in this study are the following issues. Does the upgrading of the industrial structure have a significant impact on China's economic growth? Does the structural dividend affect the economic growth positively or negatively?

For the research of the stated problems, the following hypothesis has been set: The upgrading of the industrial structure has a significant impact on China's economic growth, and the impact of structural dividend on economic growth is positive.

After introduction, the paper provides overview of main scientific contribution on the topic researched. Brief metodological explanations are given in Section 3. Section 4 provides explanation on the data sample and presents empirical results. Before conclusion short discussion of the results is given.

\section{Literature review}

The rapid growth and regional economic differences within China is a growing concern of many scholars (see e.g., Zhang and Cui, 2013; Choi, 2009; Cai and Zhang, 2015; Pant, 1996; Zhang, 2014). The upgrading of industrial structure is an important factor affecting the growth of the national economy (see e.g., Zhang and Zhou, 2010; Martínez and Rodríguez, 2010; Chen and Yang, 2016). Based on 
the panel data of 50 industries, scholars analyzed the impact of industrial structure upgrades on the economy and employment in the UK economy, and found that there are differences between industries in promoting economic growth and employment growth (see e.g., Given, 2010). Some scholars named the effect of industrial structure upgrading on economic growth as the structural dividend. Both the supply and demand levels point out the impact of structural dividend on economic growth. At the same time, scholars also analyzed the structural dividend from the input and output perspectives (see e.g., Liu and Zhang, 2008; Sun et al., 2017). From the perspective of output, the productivity of different industries is different, and the increase in the proportion of higher-productivity industries will increase the productivity of the overall national economy, and then promote it. From the perspective of input factors, the elasticity of production of factors between different industries is different (see e.g., $\mathrm{Li}, 2007)$. Factors flowing from low-production-elastic industries to high-productionelastic industries will increase the overall production elasticity of the national economy and thus promote economic growth. There is no essential difference between these two perspectives (see e.g., Eichengreen and Gupta, 2013; Han and Huang, 2016). The difference in productivity between different industries is affected by the elasticity of factor production. The optimal allocation of factors among industries will lead to an increase in the proportion of high-productivity industries and thus promote economic growth. At present, scholars' empirical research shows that in the early stages of development in China, the continuous upgrading of industrial structure is one of the driving forces for rapid economic growth (see e.g., Zhang and Wang, 2014). However, as the economy grows, this structural dividend continues to weaken.

There are still some controversies in the research methods and conclusions of the existing literature. Some studies have pointed out that the conversion share method underestimates the structural dividend, changes in the structure of capital, and even negative profits (see e.g., Zhang and Wang, 2014).

Different from the mainstream view, the conclusion of some empirical studies does not fully support the structural dividend hypothesis. Some scholars have analyzed the manufacturing industry data for 20 years in 39 market economies and found that the structural dividend is very small. This is in contrast to the United States, Japan, and the European Union. The analysis of the object is consistent. Some scholars have tried to change the original model and introduced the Vermont elasticity factor (see e.g., Eichengreen and Gupta, 2013; Han and Huang, 2016), but the conclusion still shows that the structural dividend is not large. On this basis, the scholars improved the partial assumptions and calculation problems of the traditional model, tried to select different years as the base period, changed the assumption that the marginal productivity equals the average productivity, and found that the technical results of the structural dividend had been significantly improved (see e.g., Zhang and Wang, 2014). Subsequent studies have found significant structural dividends. 
In the different stages of economic development, the size of the structural dividend changes (see e.g., Li, 2007). Based on the analysis of the manufacturing industry data after 1980 in China, it was found that the contribution rate of structural dividend to productivity growth from 1980 to 1990 was $24 \%$, but with the Chinese economy rapid growth, the structural dividend quickly decreased to 3\% after 1990 . The research on China's structural dividend also has inconsistent research findings. Some studies believe that the structural dividends of China's manufacturing industry are only $8 \%$ during the largest period (see e.g., Zhao and Cha, 2015). These literatures suggest that the labor force and capital elements are not significant in China's economic development.

Several studies have found that the industrial structure in China has the impact on urban economic growth. The upgrading of industrial structure is a key factor that can transform the production process from low efficiency to high efficiency, and thus, improve the economy's total factor productivity, thereby promoting economic growth (see e.g., Peneder M, 2003; Zhang and Wang, 2014). Further, the upgrading of industrial structure can promote the flow of resources between different departments to improve the total factor productivity and thus promote economic growth (see e.g., Liu and Zhang, 2008; Sun et al., 2017). However, some scholars found that the effect of industrial structure upgrading on economic growth is not significant (see e.g., Li, 2007), considering that alterations in the industrial structure may cause a structural slowdown in the economy (see e.g., Eichengreen and Gupta, 2013; Han and Huang, 2016).

The literature on the impact of industrial structure upgrading on economic growth has the following limitations: first, there may be a sample selection problem. There exist several studies focusing on the effects of informatisation and industrial structure upgrading the economy as a whole; however, there is lack of analysis from the perspective of economic growth of urban regions. Second, there exists a problem of model selection. There are several studies that use the panel data model, without considering the effects of regional economic spatial spillover, or the spatial econometric method, without considering space lag and the space error term at the same time (see e.g., Zhao and Cha, 2015). In this paper, we aim to address the limitations in the above literature by supplementing the existing literature with the following four aspects. Firstly, this paper introduces a model to accurately assess the impact of industrial structure on economic growth. Secondly, this article tries to find the local city of evidence for the related research of industrial structure. Further, it uses MLE estimates with the spatial autoregressive model with spatial autoregressive disturbances (SARAR) to analyze the influence of industrial structure up gradation China's urban economic growth. Subsequent research is expected to provide a policy basis to look for a new driver of economic growth under the background of the new normal economy. 


\section{Methodology}

\subsection{Theoretical framework: Cobb-Douglas production function}

This study assumes that the urban economy production function has the form of a Cobb-Douglas production function:

$$
Y_{i, t}=F_{i, t}(A, K, \text { indstr, ...) }
$$

where $Y_{i, t}$ denotes the net output level (GDP) of city $i$ during period $t, K$ and $L$ denote the capital and labor inputs, respectively, and indstr denotes the industrial structure, respectively, $A$ denotes total factor productivity (TFP). This study will analyze the source of China's urban economic growth from four perspectives, which are factor input, total factor productivity, industrial structure upgrading, and other factors.

\subsection{Spatial lag and spatial error mixed regression model}

Since there may be a spatial correlation between the different county-level economies (see e.g., Wu 2006; Zhang and Wang, 2014), this study used a spatial econometric model. The conventional spatial measurement methods include spatial lag, spatial error, and other characteristics of spatial autoregressive models as part of its considerations. However, it should be noted that the spatial lag term and spatial error term may occur at the same time, which is why the spatial autoregressive model with spatial autoregressive disturbances (SARAR) is used in this study. The mathematical expression of the SARAR model is:

$$
\begin{aligned}
& Y=\rho W X+X \beta+\mu \\
& \mu=\lambda W \mu+\varepsilon
\end{aligned}
$$

$Y$ represents the GDP of each city, $X$ represents the explained variable, $W$ represents the spatial weight matrix, $\varepsilon$ represents an independent and identically distributed random disturbance term $n \times n$ and $\varepsilon \sim N\left(0, \sigma^{2} I_{n}\right), \lambda$ is the residual auto regression coefficient, $\rho$ is the spatial auto regression coefficient, which represents the spatial effect of the total factor productivity of the county-level economy. Significant $\rho$ indicates that there is a spatial effect on the economy growth of the county-level economic entity while insignificant $\rho$ indicates that there is no spatial effect.

Due to the endogeneity of the independent variables, the use of OLS estimates is biased and inconsistent. During the research process, scholars found that the estimated parameter values of the IV method tend to exceed the defined scope and that it is hard to find a "good" instrumental variable in the empirical analysis process. However, the MLE method can avoid such problems and at the same 
time, the total factor productivity change index is a restricted dependent variable (see e.g., Wu 2006; Zhang and Wang, 2014). Therefore, this study used the Tobit maximum likelihood estimation method to estimate the SARAR model.

The spatial weight matrix $W$ used in the analysis process of this study is the adjacent matrix. For example, if county $i$ and county $j$ have common border(s), then $W_{i j}=1$. On the other hand, $W_{i j}=0$ is the opposite of the elements of the spatial weight matrix $W$ being equal to 0 on the main diagonal.

Then we derive a SARAR empirical equation from the Cobb-Douglas production function:

$$
\begin{aligned}
& \ln Y_{i, t}=\beta_{0}+\beta_{1} i s_{i, t}+\beta_{2} i_{s_{i, t}^{2}}^{2}+\beta_{3} \text { inform }_{i, t}+\beta_{4} \text { humcap }_{i, t}+\beta_{5} u r b_{i, t}+ \\
& +\beta_{6} \text { fdi }_{i, t}+\beta_{7} \text { gov }_{i, t}+\beta_{8} \text { consum }_{i, t}+\beta_{9} \text { financial }_{i, t}+\beta_{10} \operatorname{agg}_{i, t}+ \\
& +\beta_{11} \text { rail }_{i, t}+\beta_{12} \text { road }_{i, t}+\mu_{i, t}
\end{aligned}
$$

where $Y_{i, t}$ denotes the GDP of city $i$ during period $t$, is denotes the industrial structure, is ${ }^{2}$ denotes the square of the industrial structure, inform denotes the information development, humcap denotes the information development, urb denotes the Urbanization of city, $f d i$ denotes the foreign direct investment, gov denotes the Fiscal Expenditure, consum denotes the Consumer Demand Indicators, financial denotes the Financial Development Index, agg denotes the Manufacturing Agglomeration, rail and road denote the Railway and Highway Construction of the city.

\section{Empirical data and analysis}

This article focuses on 283 cities above the prefectural level in mainland China. In 2015, the total number of prefecture-level cities and above in China was 295 (including 4 municipalities, 15 sub-provincial cities, etc.). This study removed prefecture-level cities (such as Chaohu City) that had undergone changes in administrative units, also deleted the data missing cities (such as Lhasa City, Zhongwei City, Weinan City, etc.). In addition, considering the construction of the spatial weight matrix, Haikou and Sanya cities in Hainan Province were also deleted. Finally, the balanced panel data of 283 cities from 2001 to 2014 was obtained.

The original data mainly come from the compilation and calculation of the corresponding years "China City Statistical Yearbook" and "China Regional Economic Statistics Yearbook". The data of each price deflator index is from the statistical yearbook of the corresponding year and province. Samples of specific indicators and data are presented in Table 1. 
Wang Zhenhua, Sun Xuetao, Zhang Guangsheng $\bullet$ Structural dividends and economic...

Table 1: Descriptive statistical analysis of data

\begin{tabular}{|l|l|r|r|r|r|}
\hline Variable & \multicolumn{1}{|c|}{ Meaning } & Mean & \multicolumn{1}{|c|}{$\begin{array}{c}\text { Standard } \\
\text { Deviation }\end{array}$} & $\begin{array}{c}\text { Minimum } \\
\text { Value }\end{array}$ & $\begin{array}{c}\text { Maximum } \\
\text { Value }\end{array}$ \\
\hline gdp & $\begin{array}{l}\text { Per capita GDP (yuan/person) } \\
\text { the exponential }\end{array}$ & 9.6289 & 0.8599 & 7.3041 & 12.7705 \\
\hline is & Industrial structure & 2.2038 & 0.1493 & 1.0635 & 5.8587 \\
\hline inform & $\begin{array}{l}\text { International Internet users } \\
\text { (Ten thousand households) }\end{array}$ & 2.8241 & 1.3475 & 0.0000 & 8.5514 \\
\hline humcap & $\begin{array}{l}\text { Number of college students per } \\
\text { ten thousand people (people/ten } \\
\text { thousand) }\end{array}$ & 8.0958 & 11.5805 & 0.0000 & 96.8578 \\
\hline urb & $\begin{array}{l}\text { proportion of urban population } \\
\text { in the total population }\end{array}$ & 0.9337 & 0.5339 & 0.2379 & 1.0000 \\
\hline fdi & $\begin{array}{l}\text { Per capita foreign investment } \\
\text { (RMB million /person) }\end{array}$ & 6.7085 & 14.1296 & 0.0000 & 194.9881 \\
\hline gov & $\begin{array}{l}\text { Government intervention (the } \\
\text { ratio of fiscal revenue and gross } \\
\text { domestic product) }\end{array}$ & 0.0630 & 0.0350 & 0.0000 & 0.6910 \\
\hline consum & Total social consumption & 0.7450 & 0.8921 & 0.0000 & 10.6605 \\
\hline financial & $\begin{array}{l}\text { Total balance of loans from } \\
\text { financial institutions }\end{array}$ & 1.9560 & 2.9978 & 0.0000 & 48.5097 \\
\hline agg & $\begin{array}{l}\text { Manufacturing concentration } \\
\text { index }\end{array}$ & 0.9800 & 0.2270 & 0.0707 & 1.8382 \\
\hline
\end{tabular}

Source: Author's calculations

The core explanatory variable of this paper is the industrial structure upgrade index is. The specific quantitative method is $i s_{i t}=\sqrt{i s_{i t h} \times i s_{i t z}}$ where $i s_{i t h}$ represents the proportion of the value-add of secondary and tertiary industries of county $i$ to regional GDP during the period $t$. $i s_{i t z}$ represents the proportion of the value-add of tertiary industries to secondary industries in county $i$ during the period $t$, and $i$ indicates the city (see e.g., Wu 2006; Zhang and Wang, 2014).

Foreign investment, which is the measure of the effect of external investment one economic growth, has been denoted in terms of per capita foreign investment in this paper. Because foreign investment is available in dollar terms, we first convert it to RMB using the average exchange rate, and then adjust it with respect to the consumer price index in 2001, to obtain the actual value with respect to the base year. Urban human capital is measured in terms of the number of college graduates per million. Because the statistical yearbook does not include transaction costs between China's cities at various levels, this paper uses the per capita volume of the cities' railway and highway freight instead. The state's influence on economic growth at the fiscal revenue level in the urban regions accounts for a large proportion of GDP measured. The industrial concentration is measured using the 
location quotient index. This paper uses the secondary and tertiary sector location quotient index to measure the degree of industrial concentration of different regional cities $i$ in China during period $t$. The secondary sector location quotient is $a g g_{2}=\left[E_{j i t} / \sum_{j}^{3} E_{j i t}\right] /\left[\sum_{\mathrm{i}}^{285} E_{j i t} / \sum_{j}^{3} \sum_{i}^{285} E_{j i t}\right], E_{j i t}$ where $t$ is the period in which $j$ is industrial added value $i$ regional cities in China.

\subsection{Spatial correlation test}

It was necessary to perform a spatial correlation test before building a spatial econometric model. Experts and scholars use Moran's I index (see e.g., Moran, 1950), Geary's C index (see e.g., Geary, 1954), and Getis-Ord general G (see e.g., Getis and Ord, 1992) to measure the area between spatial coordinates. This article refers to research by Zhang and Wang (2014), and others who use the Moran's index statistics to estimate China's urban spatial correlation for 285 cities. Moran's I index was used in this study to statistically measure the spatial correlation of GDP between cities in China. The specific results have been presented in Table 2.

Table 2: Moran's inspection results

\begin{tabular}{|l|r|r|r|r|r|r|r|}
\hline \multicolumn{1}{|c|}{ Year } & \multicolumn{1}{c|}{2001} & \multicolumn{1}{c|}{2002} & \multicolumn{1}{c|}{2003} & \multicolumn{1}{c|}{2004} & \multicolumn{1}{c|}{2005} & \multicolumn{1}{c|}{2006} & \multicolumn{1}{c|}{2007} \\
\hline Moran's & 0.092 & 0.112 & 0.124 & 0.130 & 0.129 & 0.107 & 0.107 \\
\hline Z & 11.195 & 13.508 & 14.909 & 15.559 & 15.498 & 12.881 & 12.919 \\
\hline Year & 2008 & 2009 & 2010 & 2011 & 2012 & 2013 & 2014 \\
\hline Moran's & 0.108 & 0.108 & 0.109 & 0.104 & 0.103 & 0.092 & 0.089 \\
\hline Z & 13.061 & 12.961 & 13.106 & 12.572 & 12.400 & 11.200 & 10.752 \\
\hline
\end{tabular}

Note: Because the Moran's index for all inspection results has a spatial correlation significantly under the $1 \%$ level, it has not been marked in the table.

Source: Stata14.0 software

The results of the spatial autocorrelation test show that there are significant spatial correlations between the changes in the GDP of cities in China, which may be manifested in the form of spatial dependence and spatial spillover effects. Spatial factors have a significant effect on the change in GDP in neighboring cities. That is, the change in GDP in each city is affected to some extent by changes in GDP of neighboring cities. The Moran's I index is positive, indicating that this spatial correlation is a positive spatial spillover effect. Conventional research ignores the influence of spatial factors on the change index of GDP in cities. 


\subsection{Results of space econometric model}

First, we conduct BP inspection given the panel data. A random-effects model or a mixed effects model is more suitable for assessing panel data. Then, we use the Hausman test because a random effects model is more suitable for panel data than a fixed effects model. Because the BP inspection results are Prob $>$ chibar $^{2}=$ 0.0000 , there are no individual random effects" is strongly rejected; this implies that between" random effects" and "mixed regression," we must choose the former. Because the Hausman test results are Prob $>\mathrm{chi}^{2}=0.0000$, we strongly reject the null hypothesis that the fixed effects model is superior to the random effects model. Therefore, this article uses the random effects model for assessing the effect of industrial structure upgrading on urban economic growth. The use of the spatial autoregressive error term in the SARAR reveals the influence of the above factors on urban economic growth. The specific results as shown in Table 3.

Table 3: Spatial regression results of China's urban economic growth over 20012014

\begin{tabular}{|c|c|c|c|}
\hline Variables & SARAR & SEM & SAR \\
\hline is & $\begin{array}{r}0.658 * * * \\
(0.0947)\end{array}$ & $\begin{array}{r}0.745 * * * \\
(0.0974)\end{array}$ & $\begin{array}{r}0.569 * * * \\
(0.0982)\end{array}$ \\
\hline is $^{2}$ & $\begin{array}{r}-0.0781 * * * \\
(0.0141)\end{array}$ & $\begin{array}{r}-0.0894 * * * \\
(0.0145)\end{array}$ & $\begin{array}{r}-0.0698 * * * \\
(0.0148)\end{array}$ \\
\hline inform & $\begin{array}{r}0.0227 * * * \\
(0.00440)\end{array}$ & $\begin{array}{r}0.0219 * * * \\
(0.00454)\end{array}$ & $\begin{array}{r}0.0257 * * * \\
(0.00423)\end{array}$ \\
\hline humcap & $\begin{array}{r}0.00177 * * * \\
(0.000553)\end{array}$ & $\begin{array}{r}0.00223 * * * \\
(0.000569)\end{array}$ & $\begin{array}{l}0.00121 * * \\
(0.000580)\end{array}$ \\
\hline urb & $\begin{array}{r}0.0981 * * \\
(0.0473)\end{array}$ & $\begin{array}{c}0.101 * * \\
(0.0488)\end{array}$ & $\begin{array}{r}0.0720 \\
(0.0498)\end{array}$ \\
\hline fdi & $\begin{array}{r}0.0949 * * * \\
(0.0365) \\
\end{array}$ & $\begin{array}{r}0.0801 * * \\
(0.0376)\end{array}$ & $\begin{array}{r}0.0856 * * \\
(0.0384)\end{array}$ \\
\hline gov & $\begin{array}{r}-0.270 * * * \\
(0.0786)\end{array}$ & $\begin{array}{r}-0.240 * * * \\
(0.0810)\end{array}$ & $\begin{array}{r}-0.321 * * * \\
(0.0809) \\
\end{array}$ \\
\hline consum & $\begin{array}{l}0.112 * * * \\
(0.00714)\end{array}$ & $\begin{array}{l}0.131 * * * \\
(0.00724)\end{array}$ & $\begin{array}{l}0.130 * * * \\
(0.00690)\end{array}$ \\
\hline financial & $\begin{array}{r}0.0140 * * * \\
(0.00151)\end{array}$ & $\begin{array}{r}0.0150 * * * \\
(0.00156)\end{array}$ & $\begin{array}{r}0.0125 * * * \\
(0.00153)\end{array}$ \\
\hline agg & $\begin{array}{r}0.740 * * * \\
(0.0253)\end{array}$ & $\begin{array}{r}0.813 * * * \\
(0.0256)\end{array}$ & $\begin{array}{r}0.787 * * * \\
(0.0257)\end{array}$ \\
\hline rail & $\begin{array}{r}0.00269 * * * \\
(0.000305)\end{array}$ & $\begin{array}{r}0.00297 * * * \\
(0.000313)\end{array}$ & $\begin{array}{r}0.00403 * * * \\
(0.000354)\end{array}$ \\
\hline road & $\begin{array}{c}7.22 \mathrm{e}-05^{*} \\
(3.94 \mathrm{e}-05)\end{array}$ & $\begin{array}{c}7.18 \mathrm{e}-05^{*} \\
(4.06 \mathrm{e}-05)\end{array}$ & $\begin{array}{r}8.51 \mathrm{e}-05^{* *} \\
(4.29 \mathrm{e}-05)\end{array}$ \\
\hline
\end{tabular}


Wang Zhenhua, Sun Xuetao, Zhang Guangsheng $\bullet$ Structural dividends and economic..

\begin{tabular}{|l|r|r|r|}
\hline \multicolumn{1}{|c|}{ Variables } & \multicolumn{1}{c|}{ SARAR } & \multicolumn{1}{c|}{ SEM } & \multicolumn{1}{c|}{ SAR } \\
\hline rho & $-0.628^{* * *}$ & & $0.755^{* * *}$ \\
& $(0.0446)$ & & $(0.00965)$ \\
\hline lambda & $1.015^{* * *}$ & $1.024^{* * *}$ & \\
& $(0.00206)$ & $(0.00340)$ & \\
\hline sigma2_e & $0.0173^{* * *}$ & $0.0171^{* * *}$ & $0.0177^{* * *}$ \\
& $(0.000365)$ & $(0.000385)$ & $(0.000397)$ \\
\hline Observations & 3,962 & 3,962 & 3,962 \\
\hline R-squared & 0.657 & 0.785 & 0.734 \\
\hline Number of cities & 283 & 283 & 283 \\
\hline
\end{tabular}

Note: $* * * * *, *$ donate the significance level of $1 \%, 5 \%$ and $10 \%$ respectively. Robust standard errors are reported in the parenthesis.

Source: Stata14.0 software

Table 3 presents the estimated results, which are similar to the expected theoretical results based on equations I, II and III. The SAR model coefficient, $\rho$ and the residual autoregressive coefficient $\lambda$ are significant at the $1 \%$ level, which suggests that China's per capita GDP for regional cities is significantly impacted by location. Therefore, using a spatial econometric model is reasonable and necessary.

\section{Results and discussion}

First, we will discuss the impact of structural dividend on the economic growth of Chinese cities. According to the estimation results of the model, measuring the impact of the industrial structure on China's urban per capita GDP is positive, but the square of the industrial structure has a negative impact on the urban economic growth, and both passed the $1 \%$ significance level test. This shows that the upgrading of the industrial structure has a significant impact on the economic growth of Chinese cities, that is, there are significant structural dividends in the process of urban economic growth in China, which is consistent with the existing literature research conclusions. The essence of the upgrading of industrial structure is the reconfiguration of elements in various industries. In the process of resource reconfiguration, the elements will pursue the principle of maximizing the marginal output, and the elements will flow from the low-output industries to the high-output industries, which will correspondingly increase the output of the unit elements, that is, the upgrading of the industrial structure will bring Regional economic growth. This is consistent with the conclusions of existing studies (e.g., Kraemer and Dedrick, 2001; Meng and Li, 2002; Jin and Cho, 2015). An interesting finding is that the square of the upgrading of the industrial structure has a negative impact on economic growth and passed the $1 \%$ significance level test, that is, there is a 
significant inverted "U" relationship between the industrial structure and economic growth. The explanation given in this article is: From the perspective of production efficiency, the unit of economic output in the manufacturing sector is relatively high, while the unit of economic output in the service sector is relatively low. Therefore, in the initial stage of industrialization, the industrial structure is upgraded from agriculture to industry, and the industrial upgrading will promote economic growth. With the further economic growth, major industries will upgrade from industries to services, and industrial upgrading will not be conducive to economic output growth (see e.g., Xiao and Peng, 2013; Jiang and Liu, 2015). It should be noted that with the economic growth, we should not only judge economic output as the target, and further upgrading of the industry will have other externalities, including improving the quality of economic growth and reducing income gaps. The goal of industrial upgrading should not only be limited to promoting economic growth.

Figure 1: The structural dividend in economic growth
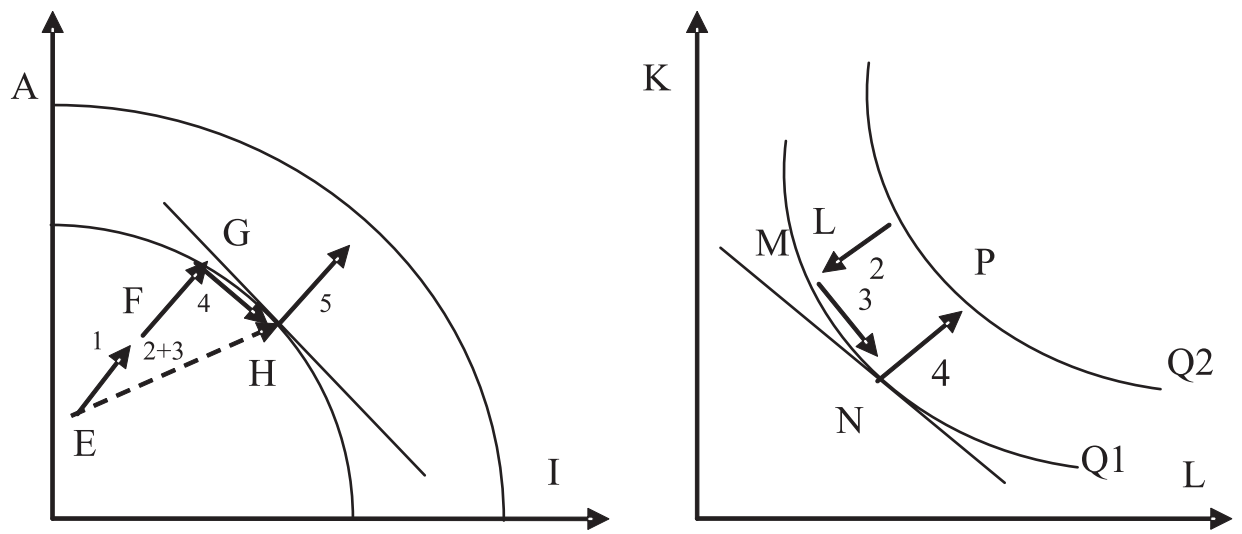

Source: Authors' drawing

This article analyzes the impact of structural dividend on economic growth based on neoclassical economic theory. Assume that the economy consists of two sectors, namely the agricultural sector and the non-agricultural sector (see e.g., Sun et al., 2017; Yu, 2015). A in Figure 1 represents the agricultural sector product, I represent the non-agricultural sector product, the left is the production possibility curve, and the right is the non-agricultural sector equal yield curve. The economic growth in the chart is divided into three processes. The first is the process of passing point $\mathrm{E}$ to point $\mathrm{G}$ from point $\mathrm{E}$ in the production probability curve and the point of production from point $\mathrm{L}$ to point $\mathrm{M}$ in the equal-production curve. The process of approaching the boundary also indicates the process of reducing the degree of inefficient use of factors and increasing the total factor productivity. The second is the process from point $\mathrm{G}$ to point $\mathrm{H}$ in the production probability curve graph and the process 
from point $\mathrm{M}$ to point $\mathrm{N}$ in the iso-yield curve represents the process of structural transformation, indicating the flow of resource elements among different industries promotes production efficiency. The third is the process of rising outward from point $\mathrm{H}$ in the production probability curve and the process of increasing from point $\mathrm{N}$ to point $\mathrm{P}$ in the iso-yield curve, indicating that the production of the economy is in an optimal state and that it is necessary to continue expanding the economy. Growth must increase the input of the factor. From the above three processes, economic growth can be divided into three sources: first, constant accumulation of input factors, second, continuous improvement in production efficiency, and third, changes in the industrial structure (see e.g., Sun et al., 2017; Yu, 2015).

This research focuses on the impact of upgrading of industrial structure on China's urban economic growth. From the perspective of the estimated results of the model, industrial structure upgrading positively influences China's urban per capita GDP. However, the quadratic term in the equation indicating industrial structure upgrading has a negative impact on China's per capita urban GDP at 1\% significance level. An examination of the impact of industrial structure upgrading on urban economic growth reveals that it exists structure dividend in the process of economic growth, which is consistent with the findings of previous research

The upgrading of industrial structure is the essence of the resource reconfiguration process between industries. In the process of resource reconfiguration, firms pursue the maximization of marginal output. Thus, firms shift from producing low industrial output to high industrial output, this increase in output leads to urban economic growth. An interesting discovery is that industrial structure upgrading also has a negative impact on China's urban economic growth at the $1 \%$ significance level. A possible explanation for this effect is that below a certain value, industrial structure upgrading leads to urban economic growth; however, if industrial structure upgrading is greater than a certain value, it hinders urban economic growth (see e.g., Xiao and Peng, 2013; Jiang and Liu, 2015).

Then we study the influence of different equations of informatization and industrial structure upgrading on the economic growth of China's prefecture-level cities. By comparing regression equations SEM and SAR, we find that the regression results are stable for the number of local telephone subscribers, the number of mobile phone users, and the number of Internet users with respect to their impact on China's urban economic growth. Further, increasing or decreasing the control variables does not affect the stability of the results. Comparing regression equations SEM and SAR, we find that primary and secondary sectors of industrial structure impact urban economic growth. Increasing or decreasing the control variables does not affect the stability of the results.

Among the control variables, we find that Information Development, Human Capital, Urbanization Development, FDI, Fiscal Expenditure, Consumer Demand 
Indicators, Financial Development, Manufacturing Agglomeration, Railway and Highway Construction positively influence urban economic growth at various significance levels. Since control variables are not the focus of this article's analysis, no discussion will be held.

According to the research experience of existing work, the panel data robustness tests generally include three categories: first, considering the variables by replacing the quantitative indicators of the core explanatory variables; second, considering the data by adjusting the sample classification according to different standards; and third, considering the measurement method. A robustness test was conducted according to the three aspects above. First, the quantitative indices of the industrial structure were replaced; second, the spatial econometric model and spatial weight matrix were replaced for the estimation.

First, the quantitative indices of the industrial structure were replaced and the robustness of the relevant conclusions was checked. A more complex statistical indicator was adopted to quantify industrial structure during the analysis process. In this section, the study drew on the experience of some research and used the proportion of non-agricultural industries to quantify the industrial structure index; that is, the proportion of the added value of secondary and tertiary industries to regional GDP was used to reflect the changes in industrial structure. The other processes of the model remained unchanged. The specific estimation results are shown in Table 4.

Table 4: Estimation results of the replaced spatial weight matrix

\begin{tabular}{|l|r|r|r|}
\hline \multicolumn{1}{|c|}{ Variables } & \multicolumn{1}{|c|}{ SARAR } & \multicolumn{1}{c|}{ SEM } & \multicolumn{1}{c|}{ SAR } \\
\hline is & $0.578^{* * *}$ & $0.699^{* * *}$ & $0.539^{* * *}$ \\
& $(0.0999)$ & $(0.0983)$ & $(0.0972)$ \\
\hline Is2 & $-0.0693^{* * *}$ & $-0.0819^{* * *}$ & $-0.0651^{* * *}$ \\
& $(0.0148)$ & $(0.0146)$ & $(0.0146)$ \\
\hline inform & $0.0269^{* * *}$ & $0.0243^{* * *}$ & $0.0253^{* * *}$ \\
& $(0.00433)$ & $(0.00457)$ & $(0.00416)$ \\
\hline humcap & $0.00135^{* *}$ & $0.00190^{* * *}$ & $0.00114^{* *}$ \\
& $(0.000586)$ & $(0.000568)$ & $(0.000574)$ \\
\hline urb & 0.0799 & $0.0952^{*}$ & 0.0721 \\
& $(0.0495)$ & $(0.0487)$ & $(0.0493)$ \\
\hline fdi & $0.0914^{* *}$ & $0.104^{* * *}$ & $0.0873^{* *}$ \\
& $(0.0382)$ & $(0.0377)$ & $(0.0380)$ \\
\hline gov & $-0.293^{* * *}$ & $-0.236^{* * *}$ & $-0.315^{* * *}$ \\
& $(0.0814)$ & $(0.0815)$ & $(0.0800)$ \\
\hline consum & $0.128^{* * *}$ & $0.126^{* * *}$ & $0.125^{* * *}$ \\
& $(0.00715)$ & $(0.00738)$ & $(0.00684)$ \\
\hline
\end{tabular}


Wang Zhenhua, Sun Xuetao, Zhang Guangsheng $\bullet$ Structural dividends and economic..

\begin{tabular}{|l|r|r|r|}
\hline \multicolumn{1}{|c|}{ Variables } & \multicolumn{1}{c|}{ SARAR } & \multicolumn{1}{c|}{ SEM } & \multicolumn{1}{c|}{ SAR } \\
\hline financial & $0.0127 * * *$ & $0.0145^{* * *}$ & $0.0122^{* * *}$ \\
& $(0.00155)$ & $(0.00156)$ & $(0.00151)$ \\
\hline agg & $0.785 * * *$ & $0.806 * * *$ & $0.764 * * *$ \\
& $(0.0277)$ & $(0.0260)$ & $(0.0255)$ \\
\hline rail & $0.00399 * * *$ & $0.00315^{* * *}$ & $0.00393 * * *$ \\
& $(0.000352)$ & $(0.000316)$ & $(0.000350)$ \\
\hline road & $8.78 \mathrm{e}-05 * *$ & $7.86 \mathrm{e}-05^{*}$ & $8.87 \mathrm{e}-05 * *$ \\
& $(4.24 \mathrm{e}-05)$ & $(4.09 \mathrm{e}-05)$ & $(4.25 \mathrm{e}-05)$ \\
\hline rho & $0.750 * * *$ & & $0.762 * * *$ \\
& $(0.0116)$ & & $(0.00951)$ \\
\hline lambda & $0.122 *$ & $0.964 * * *$ & $(0.00425)$ \\
& $(0.0627)$ & $0.0169 * * *$ & $0.0173 * * *$ \\
\hline sigma2_e & $0.0186 * * *$ & $(0.000383)$ & $(0.000389)$ \\
\hline Observations & $(0.000389)$ & 3,962 & 3,962 \\
\hline R-squared & 3,962 & 0.786 & 0.726 \\
\hline Number of cities & 0.737 & 283 & 283 \\
\hline
\end{tabular}

Note: $* * *, * *, *$ donate the significance level of $1 \%, 5 \%$ and $10 \%$ respectively. Robust standard errors are reported in the parenthesis.

Source: Stata14.0 software

Table 4 presents the regression results. It can be seen from the regression results that there is a significant inverted " $U$ " relationship between the industrial structure and economic growth, and is also significant at the $1 \%$ level; this is consistent with the regression results shown in Table 3. The effect of other control variables is similar to the benchmark regression estimation results, but since they are not the focus of this study, they are not shown to conserve space.

\section{Conclusions}

The presented results of our analysis proved the hypothesis that industrial structure upgrading is the prime reason for the economic growth and the differences in the urban economy in China, and the impact of structural dividend on economic growth is positive. However, with the further upgrading of the industrial structure, the structural dividend will become negative.

In China's new normal economic context, looking for a new economic growth point is the priority. This paper uses the SARAR to prove whether informatization and upgrading of the industrial structure can promote economic growth in China's 
prefecture-level cities. The study found the following: first, China's urban economic growth has significant spatial correlation, and the spatial correlation shows a positive spillover effect; second, the economic growth is owing to structure growth; fourthly, the upgrading of industrial structure can promote economic growth, when industrial structure upgrading is less than a certain value. However, when industrial structure upgrading is greater than a certain value, it can hinder China's urban economic growth. The study provides new empirical evidence for the new classical economic growth theory and a new research experience for a follow-up study.

The limitations of the empirical analysis are primarily related to the data availability. Due to lack of industry's internal upgrade data; we have not analyzed the influence of the upgrading of specific industries on the economic growth of cities. For the future research, the following directions can be stated: further in-depth analysis to discuss the influence of industrial agglomeration on urban economic growth; further analysis of the impact of informatization and industrial structure upgrading on Total Factor Productivity of urban economic growth.

The above conclusions contain important policy implications. Upgrading industrial structures can be a way to improve GDP of cities and the sustainable development of the regional economy. The key to upgrading industrial structure on the supply side is the process of redistribution between industries. Therefore, policymakers must ensure that the flow of factors between different industrial channels is free. The free flow of these factors is a matter that the government needs to seriously consider. Moreover, according to the theory of new structural economics, the precondition for upgrading industrial structure is upgrading the factor endowment structure. Combined with the conclusions of this study, the establishment of a platform for capital integration in cities and realization of the flow of capital elements among industries may promote an improvement in GDP in cities, as well as sustainable economic growth.

\section{References}

Cai, Y. Z., Zhang, J.N. (2015) "The Substitution and Pervasiveness Effects of ICT on China's Economic Growth", Economic Research Journal, No. 12, pp. 100114, doi: 10.3969/j.issn.1009-0843.2017.14.060.

Chen, Q. J., Yang, H. X. (2016) "Effect of Integration of Informatization and Industrialization on Energy Intensity", China Population, Resources and Environment, No. 1, pp.12-44, doi: 10.3969/j.issn.1002-2104.2016.01.008.

Choi, C., Yi, M. H. (2009) "The effect of the Internet on economic growth: Evidence from cross-country panel data", Economics Letters, Vol. 105, No. 1, pp. 39-41, doi: 10.1016/j.econlet.2009.03.028. 
Eichengreen, B., Gupta, P. (2013) "The two waves of service-sector growth", Oxford Economic Papers, Vol. 65, No. 1, pp. 96-123, doi: 10.1093/oep/gpr059.

Fan, A.J., Wang, L.L. (2009) "Regional difference of Chinese technical efficiency and growth convergence, based on the research of provincial data", Economist, No. 4, pp. 83-89, doi: 10.16158/j.cnki.51-1312/f.2009.04.007.

Geary, R. C. (1954) "The Contiguity Ratio and Statistical Mapping”, Incorporated Statistician, Vol. 5, No. 3, pp. 115-146, doi: 10.2307/2986645.

Getis. A., Ord, J. K. (1992) "The Analysis of Spatial Association by Use of Distance Statistics", Geographical Analysis, Vol. 24, No. 3, pp. 189-206, doi: 10.1111/ j.1538-4632.1992.tb00261.x.

Given, J. (2010) "Take your partners: Public private interplay in Australian and New Zealand plans for next generation broadband", Telecommunications Policy, Vol. 34, No. 9, pp. 540-549, doi: 10.1016/j.telpol.2010.07.012.

Han, Y.H., Huang, L.X. (2016) "Does Industrial Structure Upgrading Improve EcoEfficiency?", The Journal of Quantitative \& Technical Economics, No. 4, pp. 4059, doi: 10.13653/j.cnki.jqte.2016.04.003.

Huang, Q.H. (2014) "The New Normal, the Late Stage of Industrialization and the New Power of Industrial Growth", China Industrial Economics, No. 10, pp. 5-19, doi: 10.19581/j.cnki.ciejournal.2014.10.001.

Jiang, W.L., Liu, R.X. (2015) "Rising wage costs under the perspective of the optimal measure analysis of industrial structure", Statistics \& Decision, No. 22, pp. 127-131, doi: 10.13546/j.cnki.tjyjc.2015.22.036.

Jin, S., Cho, C.M. (2015) "Is ICT a new essential for national economic growth in an information society?", Government Information Quarterly, Vol. 113, No. 1, pp. 54-58, doi: 10.1016/j.giq.2015.04.007.

Jovanovic, B., Rousseau, P.L. (2005) "Chapter 18-General Purpose Technologies", Handbook of Economic Growth, Vol. 1, No. 5, pp. 1181-1224, doi: 10.1016/ S0169-7218(10)02002-2.

Kraemer, K. L., Dedrick, J. (2001) "Information Technology and Economic Development: Results and Policy Implications of Cross-Country Studies", Information Technology, Productivity and Economic Growth, doi: 10.1093/acpr of:oso/9780199243983.003.0012.

Krugman, P. (1994) "The Myth of Asia's Miracle: A Cautionary Fable", Foreign Affairs, Vol. 73, No. 6, pp. 62-68, doi: dx.doi.org/10.2307/20046929.

Li, X.P. (2007) "Structural changes and productivity growth in China's manufacturing industry", The Journal of World Economy, Vol. 30, No. 5, pp. 5264, doi: 10.3969/j.issn.1002-9621.2007.05.006.

Liu, W., Zhang, H. (2008) "Structural Change and Technical Advance in China's Economic Growth", Economic Research Journal, No. 11, pp. 4-15, doi: 10.3969/j.issn.2095-4549.2017.18.212. 
Martínez, D., Rodríguez, J. (2010) "ICT-specific technological change and productivity growth in the US: 1980-2004", Information Economics \& Policy, Vol. 22, No. 2, pp. 121-129, doi: 10.1016/j.infoecopol.2009.07.001.

Meng, Q., Li, M. (2002) "New Economy and ICT development in China", Information Economics \& Policy, Vol. 14, No. 2, pp. 275-295, doi: dx.doi. org/10.1016/S0167-6245(01)00070-1.

Moran, P. A. (1950) "Notes on Continuous Stochastic Phenomena", Biometrika, Vol. 37, No. 1/2, pp. 17-23, doi: dx.doi.org/10.2307/2332142.

Pant, Darshan D. (1996) "The biogeography of the late Paleozoic floras of India", Review of Palaeobotany \& Palynology, Vol. 90, No. 1, pp.79-98, doi: 10.1016/0034-6667(95)00025-9.

Peneder, M. (2003) "Industrial structure and aggregate growth", Structural Change \& Economic Dynamics, Vol. 14, No. 4, pp. 427-448, doi: 10.1016/S0954349X(02)00052-8.

Research Grop on China's Economic Growth. (2014) "The Shock of Low Inefficiency to China's Economic Growth and the Governance of Economic Slowdown", Economic Research Journal, No. 12, pp. 4-17, doi: 10.3969/j.issn. 1006-3102.2014.12.138.

Sun, X.T., Wang, Z.H., Zhang, G.S. (2017) "Research on the Influence of Technological Progress Bias on Industrial Structure and Its Spillover Effects", Journal of Shanxi University of Finance and Economics, Vol. 39, No. 11, pp. 5668, doi: 10.13781/j.cnki.1007-9556.2017.11.005.

Wu, Y.M. (2006) "A Spatial Econometric Model and Its Application to Research\& Development and Regional Innovation", The Journal of Quantitative \& Technical Economics, No. 5, pp. 74-85+130, doi: 10.3969/j.issn.1000-3894. 2006.05.009.

Xiao, X.Z., Peng, Y.Z. (2013) "China's Optimal Industrial Structure: The Theoretical Model and Quantitative Calculation", China Economic Quarterly, No. 1, pp. 135-162, doi: 10.13821/j.cnki.ceq.2013.01.011.

Yu, B.B. (2015) "Economic Growth Effects of Industrial Restructuring and Productivity Improvement-Analysis of Dynamic Spatial Panel Model With Chinese City Data", China Industrial Economics, No. 12, pp. 83-98, doi: 10.19581/ j.cnki.ciejournal.2015.12. 007.

Zhang, G.S., Wang, Z.H. (2014) "The measure of Structural Bonus and Influence Factors in County Economy", Economic Theory and Business Management, No. 6, pp. 102-112, doi: 10.3969/j.issn.1000-596X.2014.06.009.

Zhang, H.L., Zhou, Q. (2010) "Information Technology, Network Effect and Provincial Economic Growth in China: Empirical Analysis Based on the Spatial Perspective", China Soft Science, No. 10, pp. 112-123+179, doi: 10.3969/j.issn. 1002-9753.2010.10.014. 
Zhang, Y.L., Cui Q. (2013) "The Integration Evaluation between Industrialization and Informatization in China", Science Research Management, No. 4, pp. 43-49, doi: 10.19571/j.cnki.1000-2995.2013.04.006.

Zhang, Y.L. (2014) "Network, Information Pool and Time Duplicate: Duplicate Economic Model", Economic Research Journal, No. 2, pp. 171-182, doi: 10.19571/j.cnki.1000-2995.2013.04.006.

Zhao, X., Cha, H.W. (2015) "Correlation Analysis of Industrial Structure Evolution and Informatization Development Level", China Population, Resources and Environment, No. 7, pp. 84-88, doi: 10.3969/j.is sn.1002-2104. 2015.07.012.

\title{
Strukturne dividende i gospodarski rast $\mathrm{u} \mathrm{Kini}^{1}$
}

\author{
Wang Zhenhua' ${ }^{2}$, Sun Xuetao ${ }^{3}$, Zhang Guangsheng ${ }^{4}$
}

\begin{abstract}
Sažetak
Cilj ovog istraživanja je analizirati utjecaj poboljšanja industrijske strukture na gospodarski rast Kine. Temeljem panel podataka o 283 gradova Kine u periodu od 2001. do 2014.godine, ovaj rad koristi prostorne panel podatke SARAR kako bi se analizirao utjecaj unapređenja industrijske strukture na gospodarski rast kineskih gradova na razini prefektura. Rezultati pokazuju da urbani gospodarski rast Kine ima značajnu prostornu korelaciju: modernizacija industrijske strukture glavni je razlog gospodarskog rasta i razlika u urbanom gospodarstvu u Kini, a utjecaj strukturalne dividende na gospodarski rast je pozitivan. Međutim, s daljnjom nadogradnjom industrijske strukture, strukturna dividenda će postati negativna, tj. postoji obrnuti odnos u obliku slova " $U$ " između industrijske strukture $i$ gospodarskog rasta. Studija daje nove empirijske dokaze o novoj klasičnoj teoriji ekonomskog rasta i novom istraživačkom iskustvu za daljnja istraživanja.
\end{abstract}

Ključne riječi: nadogradnja industrijske strukture, strukturne dividende, SARAR model, Kina

JEL klasifikacija: $C 25,011, O 13$

1 Ovaj rad je nastao uz financijsku potporu National Natural Science Foundation of China/ Nacionalne zaklade za prirodne znanosti Kine (br. 71503173), Social Science Foundation of Liaoning Province/Zaklade za društvene znanosti provincije Liaoning (br. L17AJY009) I Shenyang Science and Technology Plan Project (1801612).

2 Docent, College of Economics and Management, Shenyang Agricultural University, Shenyang 110866, Kina. Znanstveni interes: razvojna ekonomija. Tel.: +86 24 88487153. E-mail: wangzhenhuasyau@163.com.

3 Doktor ekonomskih znanosti, College of Economics and Management, Shenyang Agricultural University, Shenyang 110866, Kina. Znanstveni interes: razvojna ekonomija. Tel.: +86 24 88487248.E-mail: qingbingsun@126.com.

${ }^{4}$ Redoviti profesor, College of Business, Liaoning University, Shenyang 110136, Kina. Znanstveni interes: razvojna ekonomija.Tel.: +8613674283521.E-mail: huagewzhwzh@163. com (osoba za kontakt). 